\title{
IDENTIFIKASI JENIS KANTONG SEMAR (Nepenthes spp) DI HUTAN PENYANGGA DUSUN SEPAN DESA LANJAK DERAS KECAMATAN BATANG LUPAR KABUPATEN KAPUAS HULU
}

\author{
Identification the sepcies of Nepenthes (Nepenthes spp) in the Buffor Forest of Sepan sub-village of \\ Lanjak Deras Batang Lupar sub-district Kapuas Hulu Regency.
}

Fitri Wulandari, Gusti Eva Tavita, Siti Latifah

Fakultas Kehutanan Universitas Tanjungpura Pontianak. Jl. Daya Nasional Pontianak 78124

Email : fitri.wullandari94@gmail.com

\begin{abstract}
Nepenthes is a type of liana plant (vines) that can grow and develop in the tropical rain forest area. Nepenthes' appearance is very exotic because at of the leaf sheet pockets, appear with different colors and sizes. The unique characteristic that makes this plants different from others. The ability to catch insects that are used as nutrients to help their growth and development, marked by the formation of pockets at the tips of their leaves. The purpose of this research is to identify the species and sites of Nepenthes growth. Obtaining Nepenthes data found in the buffer forests of Sepan sub-village, Lanjak Deras Village, Batang Lupar District, Kapuas Hulu Regency. This study used a field survey method, with multiple plot technique. 45 observational plots were made with a size of $2 \times 2$ meters each. Six Nepenthes species were found, namely $N$. ampullaria, N. bicalcarata, N. gracilis, N. mirabilis, $N$. rafflesiana, N. reinwardtiana. The most common type found in the study site in the Buffor Forest Sepan sub-village, Lanjak Deras Village, is the type of Nepenthes gracilis with a total of 829 individuals. The fewest species found were Nepenthes bicalcarata with 17 individuals. Five from the six types of Nepenthes spp found at the research location were in the IUCN Red List, namely N. ampullaria, $N$. gracilis, $N$. mirabilis, $N$. rafflesiana and $N$. reinwardtiana included in conservation status, Least Concern (LC) or low risk (IUCN Red List, 2016)
\end{abstract}

Keywords: Identification, Lanjak Deras sub-village, Nepenthes.

Abstrak

Nepenthes merupakan jenis tanaman liana (sulur) yang dapat tumbuh dan berkembang di kawasan hutan hujan tropis. Penampilan Nepenthes sangat eksotik karena pada kantong-kantong lembaran daun, muncul dengan warna dan ukuran yang berbeda. Ciri khas yang membuat tanaman ini berbeda dari yang lain. Kemampuan menangkap serangga yang digunakan sebagai nutrisi untuk membantu pertumbuhan dan perkembangannya, ditandai dengan terbentuknya kantong-kantong pada ujung daunnya. Penelitian ini bertujuan untuk mengidentifikasi spesies dan tempat tumbuhnya Nepenthes. Memperoleh data Nepenthes yang ditemukan di hutan penyangga Dusun Sepan, Desa Lanjak Deras, Kecamatan Batang Lupar, Kabupaten Kapuas Hulu. Penelitian ini menggunakan metode survei lapangan, dengan teknik multiple plot. Dibuat 45 petak pengamatan dengan ukuran masing-masing $2 x$ 2 meter. Enam spesies Nepenthes yang ditemukan yaitu N. ampullaria, N. bicalcarata, N. gracilis, $N$. mirabilis, N. rafflesiana, N. reinwardtiana. Jenis yang paling banyak ditemukan di lokasi penelitian di Dusun Sepan Hutan Kerbau, Desa Lanjak Deras, adalah jenis Nepenthes gracilis dengan jumlah total 829 individu. Jenis yang paling sedikit ditemukan adalah Nepenthes bicalcarata dengan jumlah 17 individu. Lima dari enam jenis Nepenthes spp yang ditemukan di lokasi penelitian berada dalam Daftar Merah IUCN, yaitu N. ampullaria, N. gracilis, N. mirabilis, N. rafflesiana dan N. reinwardtiana termasuk dalam status konservasi, Least Concern (LC) atau berisiko rendah (Daftar Merah IUCN, 2016)

Kata kunci : Identifikasi, Nepenthes, Dusun Lanjak Deras. 


\section{PENDAHULUAN}

Kantong semar merupakan jenis tumbuhan liana (merambat) yang dapat tumbuh dan berkembang pada kawasan hutan hujan tropis. Penampilan kantong semar sangat eksotik karena di ujung lembaran daun muncul kantong, warna, dan ukuran dengan berbagai motif yang berbeda-beda (Mansur, 2006). Tumbuhan ini memiliki ciri yang sangat khas yang membuat jenis ini berbeda dengan tumbuhan yang lain yaitu mempunyai kemampuan untuk menangkap serangga yang dijadikan sebagai nutrisi untuk membantu pertumbuhan dan perkembangannya, ditandai dengan terbentuknya kantong pada ujung daunnya. Keunikan yang lain dari tumbuhan ini adalah bentuk kantong yang bervariasi, ukuran serta corak dari daun dan kantongnya (Fathul et al, 2007). Kantong semar merupakan tumbuhan yang dilindungi berdasarkan Undang-Undang No. 5 tahun 1990 tentang konservasi sumberdaya hayati dan ekosistem dan Peraturan Pemerintah RI. No. 7 tahun 1999 tentang pengawetan jenis tumbuhah dan satwa. Flora ini masuk dalam data IUCN (International Union for The Conservation of Nature, 2013).

Kantong semar hidup di dataran rendah sampai dataran tinggi mulai dari pantai sampai pegunungan (Mardianto, 2015). Kantong semar tersebar mulai dari Indonesia, Malaysia dan Filipina. Indonesia merupakan salah satu wilayah penyebaran kantong semar di dunia. Terdapat 68 jenis dan 59 jenis berstatus endemik (Mansur, 2013). Wilayah penyebaran di Indonesia meliputi Kalimantan, Sumatera, Irian Jaya, Jawa dan Sulawesi. Kalimantan merupakan pusat penyebaran kantong semar di Indonesia (Clarke, 2000). Di Kalimantan sendiri terdapat 32 jenis kantong semar dari 64 jenis yang ada di Indonesia. Sampai saat ini tercatat 103 jenis Kantong semar yang sudah dipublikasikan (Firstantinovi dan Karjono, 2006). Penelitian yang dilakukan di Kebun Raya Sambas Kecamatan Subah Kabupaten Sambas yaitu Nepenthes ampullaria Jack, Nepenthes reinwardtiana Jack, Nepenthes rafflesiana Jack, Nepenthes xhookeriana dan Nepenthes mirabilis druce. (Hairunnisah, 2018). Penelitian di berbagai kondisi tutupan hutan sekunder Desa Bukit Batu Kecamatan Sungai Kunyit ditemukan empat jenis kantong semar antara lain Nepenthes ampullaria, Nepenthes bicalcarata, Nepenthes gracilis dan Nepenthes rafflesiana. (Kristianus, 2018). Penelitian Identifikasi Jenis Kantong Semar (Nepenthes spp) Dalam Kawasan Taman Wisata Alam Gunung Asuansang KecamatanM Paloh Kabupaten Sambas ditemukan Ada lima jenis kantong semar antara lain $N$. ampullaria Jack, $N$. gracilis Korth, N. mirabilis (Lour) Druce, $N$. rafflesiana Jack dan $N$. echinostoma (Mardianto, 2015). Untuk ikut serta dalam menjaga kelestarian tumbuhan kantong semar tersebut, maka di lakukan penelitian serupa berjudul "Identifikasi Jenis Kantong Semar di Hutan Penyangga Dusun Sepan Desa Lanjak Deras Kecamatan 


\section{Batang Lupar Kabupaten Kapuas Hulu."}

Hutan penyangga dusun Sepan Desa Lanjak Deras Kecamatan Batang Lupar mempunyai potensi flora dan fauna yang cukup banyak dan menarik, satu diantaranya adalah kantong semar. Oleh sebab itu, kantong semar perlu mendapatkan perhatian khusus dalam pelestarian dan perlindungan guna mempertahankan ekosistemnya di hutan. Selain itu, jenis kantong semar di Hutan penyangga Dusun Sepan masih belum dilakukan identifikasi, sehingga sangat disayangkan apabila sebagian besar keragaman jenis kantong semar tersebut hilang dan belum sempat diidentifikasi jenis dan jumlahnya.

\section{METODE PENELITIAN}

Pengambilan data Identifikasi Jenis Kantong Semar dilaksanakan \pm 2 minggu di Hutan Penyangga Dusun Sepan Desa Lanjak Deras Kecamatan Batang Lupar Kabupaten Kapuas Hulu, dimulai dari tanggal 1 September 2019 sampai 15 September 2019 dan dilanjutkan dengan mengidentifikasi jenis-jenis kantong semar yang telah didapatkan. Alat yang digunakan dalam penelitian adalah Alat yang digunakan dalam penelitian adalah Peta lokasi skala $1: 1.500$. Kamera. GPS. Tally sheet. Alat tulis menulis. Buku Identifikasi untuk mengidentifikasi jenis-jenis kantong semar. Parang. Penggaris. Thermohigrometer. Meteran dan tali rafia. Kaliper untuk mengukur diameter lingkaran batang. Objek penelitian ini adalah semua jenis kantong semar ( Nepenthes spp ) yang terdapat pada jalur kawasan Hutan Penyangga Dusun Sepan Desa Lanjak Deras Kecamatan Batang Lupar Kabupaten Kapuas Hulu. Penelitian menggunakan metode survey, dengan teknik petak ganda. Petak pengamatan diletakkan secara purposive sampling. Ukuran petak pengamatan yang digunakan adalah $2 \mathrm{~m} \times 2 \mathrm{~m}$ dengan keseluruhan jumlah petak 45. Pengamatan dengan luas areal penelitian 3.216 Ha. Untuk mengidentifikasi parameter yang di amati berupa foto-foto morfologi, batang, kantong dan warna, serta data yang didapatkan langsung di lapangan akan diidentifikasi dengan berpedoman pada buku determinasi : Nepenthes yang Unik (Mansur, 2006). Data yang diamati dalam penelitian ini yaitu, jenis kantong semar, jumlah jenis, jumlah individu masing-masing kantong semar, pada petak pengamatan yang telah ditentukan.

Data yang diamati dalam penelitian ini adalah, jenis kantong semar, jumlah jenis, jumlah individu masing-masing kantong semar, pada petak pengamatan yang telah ditentukan. 


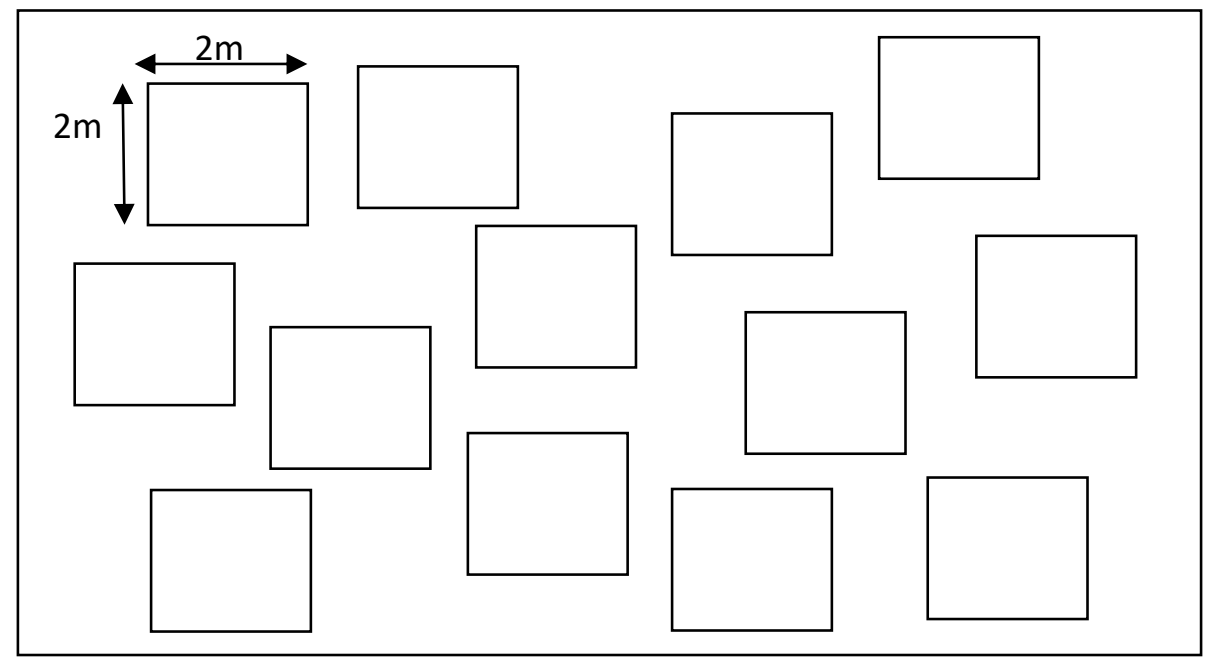

Gambar 1. Petak contoh pengamatan Kantong Semar ukuran 2m x 2m (Observation plot Nepenthes size 2m $x 2 m$ )

HASIL DAN PEMBAHASAN

\section{A. Jenis dan Jumlah Individu}

\section{Kantong Semar}

Hasil penelitian yang dilakukan di lapangan selama \pm 2 minggu di kawasan Hutan Penyangga Dusun Sepan Desa Lanjak Deras Kecamatan Batang Lupar Kabupaten Kapuas Hulu ditemukan enam jenis kantong semar. Jenis-jenis tersebut adalah Nepenthes ampullaria Jack, Nepenthes bicalcarata Hook.f. Nepenthes gracilis Korth, Nepenthes mirabilis (Lour) Druce, Nepenthes rafflesiana Jack, dan Nepenthes reinwardtiana Miq.

Jenis yang paling banyak ditemukan pada lokasi penelitian di Hutan Penyangga Dusun Sepan Desa Lanjak Deras adalah jenis Nepenthes gracilis Korth dengan jumlah 829 individu. Dengan tiga warna dan corak yang berbeda pada Nepenthes gracilis Korth. Jenis yang paling sedikit ditemukan adalah jenis Nepenthes bicalcarata Hook.f. Banyaknya jumlah individu Nepenthes gracilis yang ditemukan pada lokasi penelitian kondisi tanah yang berawa membuktikan bahwa kantong semar dapat hidup pada kondisi tanah yang marginal dengan $\mathrm{pH}$ tanah $<4$. (Mansur, 2006). Nepenthes gracilis merupakan jenis yang dominan pada lokasi ini. Hal ini menunjukkan bahwa tempat tumbuh $N$. gracilis cocoknya kondisi tempat tumbuh seperti kelembaban udara, suhu udara, sinar matahari, $\mathrm{pH}$ tanah dan ruang tumbuh dengan jenis-jenis lainnya, merupakan tempat yang cocok sehingga jenis ini ditemukan.

\section{B. Komposisi kantong Semar}

\section{(Nepenthes spp)}

Berdasarkan

pengamatan dilapangan pada kawasan Hutan Penyangga Dusun Sepan Desa Lanjak Deras Kecamatan Batang Lupar Kabupaten Kapuas Hulu terdapat enam jenis kantong semar. Keenam jenis kantong semar yang ditemukan ini tumbuh pada kawasan dan kondisi tanah rawa. Jenis kantong semar yang ada di lokasi pengamatan ini berada pada 
ketinggian 0-42 mdpl. Hal ini berarti semua jenis kantong semar yang ditemukan pada lokasi penelitian di Hutan Penyangga Dusun Sepan Desa Lanjak Deras masuk dalam karegori dataran rendah.
Jenis kantong semar yang ditemukan pada kondisi tanah berawa dan berlumut. Pada Tabel 1 dapat dilihat suhu udara pada lokasi penelitian, berikut :

\section{Tabel 1. Suhu Udara dan Kelembaban Pada Lokasi Penelitian (Temperature and} Humidity)

\begin{tabular}{|c|c|c|c|c|c|c|}
\hline \multirow[b]{2}{*}{ No Petak } & \multicolumn{2}{|c|}{ 07:30-08:30 } & \multicolumn{2}{|c|}{ 12:00-13:00 } & \multicolumn{2}{|c|}{$15: 30-16: 30$} \\
\hline & $\begin{array}{l}\text { Suhu } \\
\text { Udara }\end{array}$ & Kelembaban & $\begin{array}{l}\text { Suhu } \\
\text { Udara }\end{array}$ & Kelembaban & $\begin{array}{l}\text { Suhu } \\
\text { Udara }\end{array}$ & Kelembaban \\
\hline 1.2 .3 .4 .5 & $25,7^{\circ} \mathrm{C}$ & $80 \%$ & $30,5^{\circ} \mathrm{C}$ & $81 \%$ & $28,6^{\circ} \mathrm{C}$ & $80 \%$ \\
\hline 6.7.8.9.10 & $26,8^{\circ} \mathrm{C}$ & $78 \%$ & $30,8^{\circ} \mathrm{C}$ & $80 \%$ & $28,2{ }^{\circ} \mathrm{C}$ & $80 \%$ \\
\hline 11.12 .13 .14 .15 & $25,3^{\circ} \mathrm{C}$ & $80 \%$ & $28,8^{\circ} \mathrm{C}$ & $81 \%$ & $27,6^{\circ} \mathrm{C}$ & $80 \%$ \\
\hline 16.17.18.19 & $24,8^{\circ} \mathrm{C}$ & $78 \%$ & $27,6{ }^{\circ} \mathrm{C}$ & $80 \%$ & $27,5^{\circ} \mathrm{C}$ & $80 \%$ \\
\hline 20.21.22.23. & $24,7^{\circ} \mathrm{C}$ & $81 \%$ & $28,1{ }^{\circ} \mathrm{C}$ & $80 \%$ & $27,7^{\circ} \mathrm{C}$ & $80 \%$ \\
\hline 24.25.26.27 & $25,7^{\circ} \mathrm{C}$ & $79 \%$ & $30,2{ }^{\circ} \mathrm{C}$ & $80 \%$ & $28,5^{\circ} \mathrm{C}$ & $79 \%$ \\
\hline 28.29.30.31.32 & $25,5^{\circ} \mathrm{C}$ & $80 \%$ & $30,7^{\circ} \mathrm{C}$ & $80 \%$ & $25,8^{\circ} \mathrm{C}$ & $81 \%$ \\
\hline 33.34.35.36 & $24,6{ }^{\circ} \mathrm{C}$ & $77 \%$ & $28,8^{\circ} \mathrm{C}$ & $79 \%$ & $26,5^{\circ} \mathrm{C}$ & $79 \%$ \\
\hline 37.38.39.40 & $26,2{ }^{\circ} \mathrm{C}$ & $80 \%$ & $30,5^{\circ} \mathrm{C}$ & $81 \%$ & $27,5^{\circ} \mathrm{C}$ & $80 \%$ \\
\hline 41.42 .43 .44 .45 & $25,2{ }^{\circ} \mathrm{C}$ & $79 \%$ & $28,5^{\circ} \mathrm{C}$ & $80 \%$ & $28.1^{\circ} \mathrm{C}$ & $80 \%$ \\
\hline
\end{tabular}

\section{Deskripsi Kantong Semar (Nepenthes spp)}

Kantong semar yang ditemukan pada lokasi penelitian mempunyai ciriciri ukuran, warna dan bentuk kantong yang berbeda-beda satu dengan yang lainnya. Pada hasil pengamatan dilapangan terdapat 6 jenis kantong semar dengan ukuran, warna dan bentuk kantong yang berbeda-beda diantarannya yaitu :

\section{Nepenthes ampullaria Jack}

Nepenthes ampullaria hijau muda corak merah (Gambar 2) ditemukan pada petak ke-2 dengan jumlah 27 individu pada ketinggian $35 \mathrm{mdpl}$ dan petak ke-25 dengan jumlah 15 individu pada ketinggian $40 \mathrm{mdpl}$. Warna daun hijau tua, bentuk daun sudip hingga lanset. Panjang daun 20-25 cm, lebar daun 4-6 $\mathrm{cm}$. Panjang sulur 5-8 cm. Panjang batang 6-15 cm, diameter batang 2-3 cm. Kantong berbentuk telur. Panjang kantong 5-6 cm, lebar kantong 3-5 cm. Warna kantong hijau muda bercorak merah.
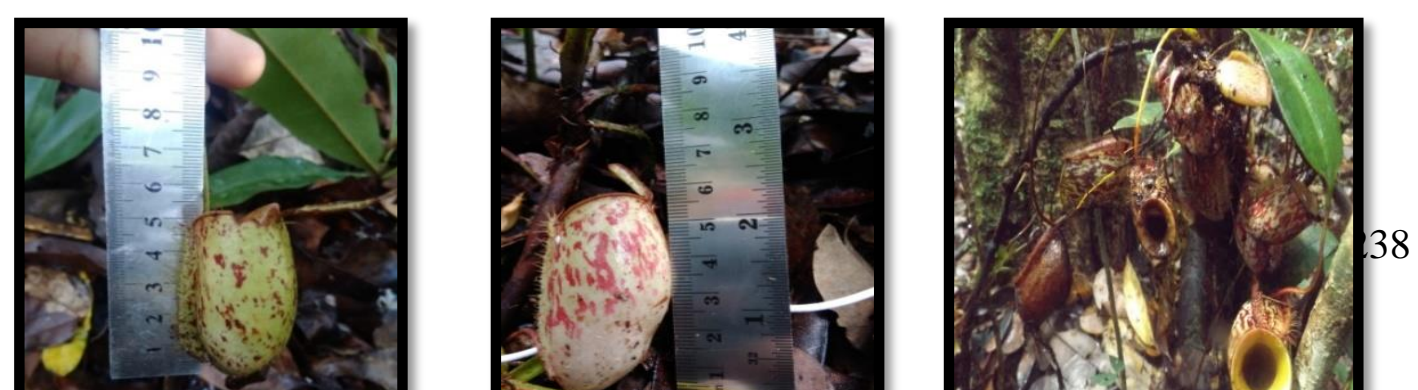


\section{Gambar 2. Nepenthes ampullaria hijau muda corak merah (Nepenthes} ampullaria light green color red (HMM)

\section{Nepenthes ampullaria merah tua} corak merah (MTM)

Nepenthes ampullaria merah tua corak merah (Gambar 3) ditemukan pada petak ke-37 dengan jumlah 25 individu pada ketinggian 37 mdpl. Warna daun hijau tua, bentuk daun lanset. Panjang daun 18-20 cm, lebar daun 4-6 cm. Panjang sulur 10-15 cm.Panjang batang 20-25 cm, diameter batang 2-3 cm. Kantong berbentuk telur. Panjang kantong 3,5-5 cm, lebar kantong 2-4 $\mathrm{cm}$.Warna kantong merah tua corak merah.
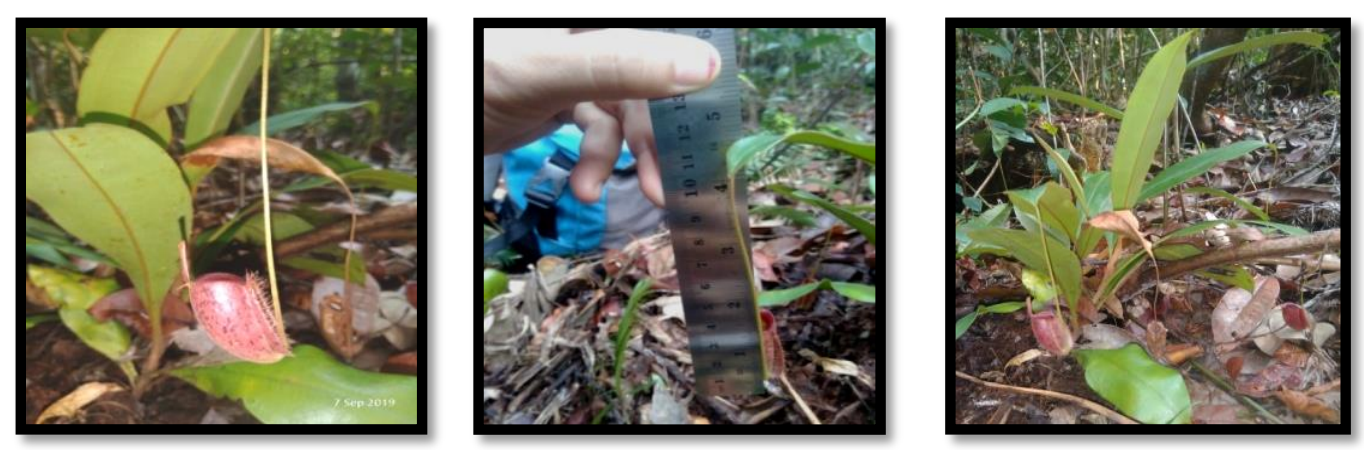

Gambar 3. Nepenthes ampullaria warna merah tua corak merah (Nepenthes ampullaria deep red color red. (MTM)

\section{Nepenthes ampullaria hijau muda (HM)}

Nepenthes ampullaria hijau muda (Gambar 4) ditemukan pada petak ke-24 dengan jumlah 20 individu, pada ketinggian $41 \mathrm{mdpl}$ dan petak ke-38 dengan jumlah 18 individu pada ketinggian 38 mdpl. Warna daun hijau muda, bentuk daun lanset. Panjang daun 15-25 cm, lebar daun 4,5-6 cm.Panjang sulur $8-15 \mathrm{~cm}$. Panjang batang $25-30 \mathrm{~cm}$, diameter batang 2-3 cm. Kantong berbentuk telur. Panjang kantong 5-7 $\mathrm{cm}$, lebar kantong 3,5-5 cm. Warna kantong hijau muda. Perbedaan warna ini disebabkan perbedaan tutupan vegetasi yang terdapat disekitar tempat tumbuh kantong semar sehingga berpengaruh pada sinar matahari yang masuk.
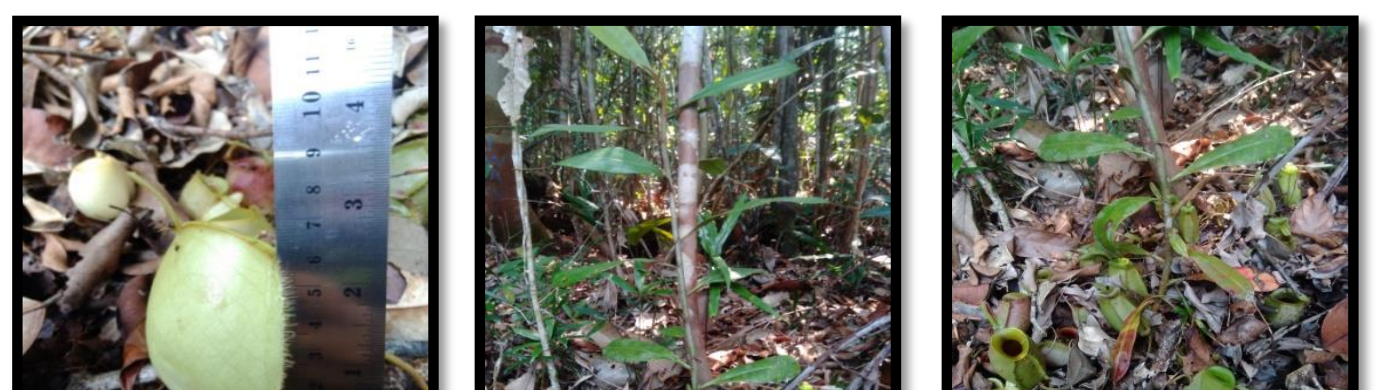


\section{Gambar 4. Nepenthes ampullaria warna hijau muda (Nepenthes ampullaria light green color (HM)}

\section{Nepenthes bicalcarata Hook.f.}

Nepenthes bicalcarata (Gambar 5) ini ditemukan pada petak ke-3 dengan jumlah 17 individu pada ketinggian 39 mdpl. Warna daun hijau tua, bentuk daun sudip hingga lanset, panjang daun 60 $\mathrm{cm}$, lebar daun $13 \mathrm{~cm}$. Panjang sulur 20 $\mathrm{cm}$, panjang batang $6 \mathrm{~cm}$, diameter batang $3 \mathrm{~cm}$. Bentuk kantong tempayan, panjang kantong $7 \mathrm{~cm}$, lebar kantong 10 $\mathrm{cm}$. Warna kantong hijau muda, terdapat taring pada kantong.
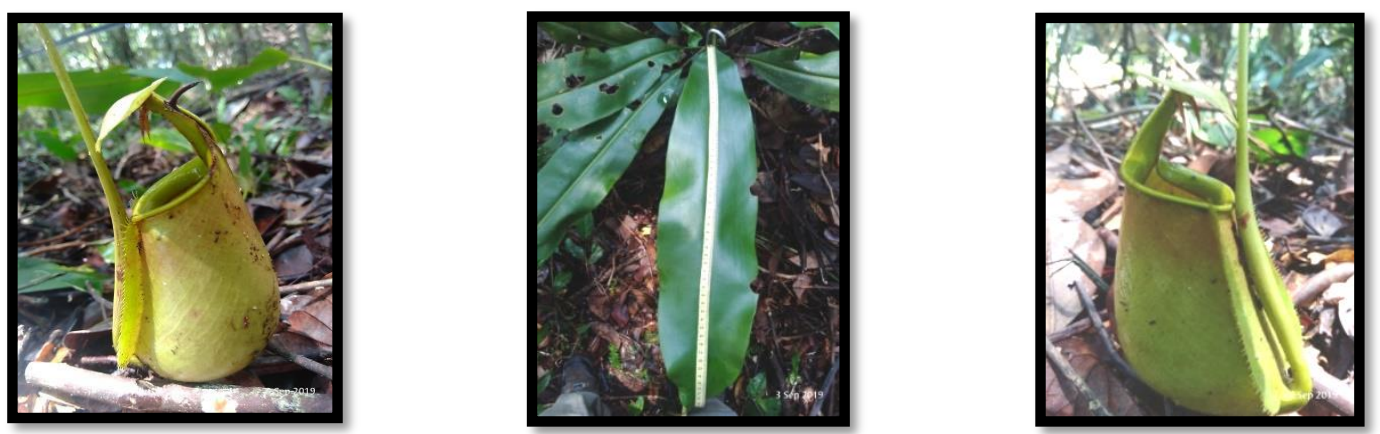

\section{Gambar 5. Nepenthes bicalcarata Hook.f.}

\section{Nepenthes gracilis Korth}

Nepenthes gracilis merah tua (MT)

Nepenthes gracilis merah tua

(Gambar 6) ditemukan pada petak ke-10 sebanyak 60 individu pada ketinggian 40 mdpl. Petak ke-14 sebanyak 84 individu pada ketinggian 39 mdpl. Petak ke-15 sebanyak 100 individu pada ketinggian 38 mdpl. Petak ke-21 sebanyak 35 individu pada ketinggian $35 \mathrm{~m}$ dpl. Petak ke-22 sebanyak 28 individu pada ketinggian 36 mdpl. Petak ke-23 sebanyak 15 individu pada ketinggian 35 mdpl. Petak ke-26 sebanyak 20 individu pada ketinggian 37 mdpl. Petak ke-27 sebanyak 18 individu pada ketinggian 37 mdpl dan petak ke-43 sebanyak 108 individu di ketinggian 40 mdpl. Warna daun hijau kemerahan, bentuk daun lanset, panjang daun 10-20 cm. Lebar daun 2-3 cm. Panjang sulur 3-5 cm, panjang batang $25-35 \mathrm{~cm}$, diameter batang 2-2,5 cm. Bentuk kantong pinggang, bentuk kantong ini merupakan identifikasi di hubungkan dengan sulur 
di ujung sulur akan berbentuk kantong (Mansur, 2006). Panjang kantong 2-5 $\mathrm{cm}$, lebar kantong 2-3 cm. Warna
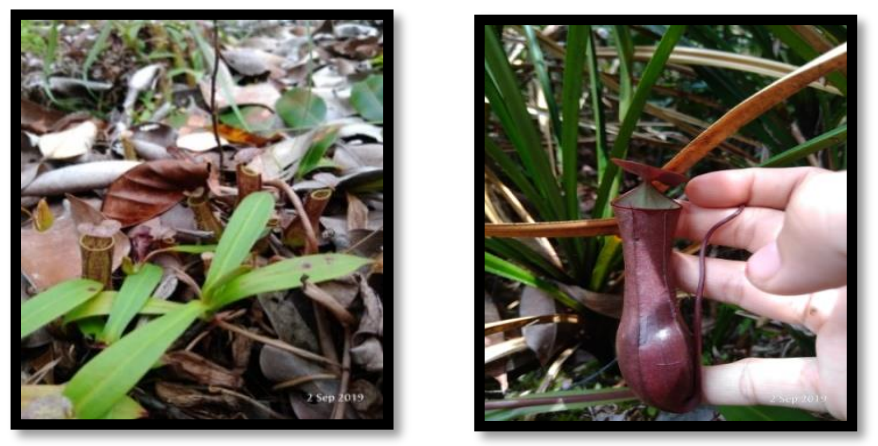

\section{Gambar 6. Nepenthes gracilis warna merah tua (Nepenthes gracilis dark red color (MT)}

Nepenthes gracilis hijau muda (HM)

Nepenthes gracilis hijau muda

(Gambar 7) ditemukan pada petak ke-30 sebanyak 20 individu di ketinggian 41 mdpl. Petak ke-31 sebanyak 10 individu pada ketinggian 39 mdpl. Petak ke-32 sebanyak 27 individu pada ketinggian 39 mdpl. Petak ke-35 sebanyak 12 individu pada ketinggian 40 mdpl dan petak ke- kantong merah tua. Dengan kondisi vegetasi yang agak terbuka dan tertutup.
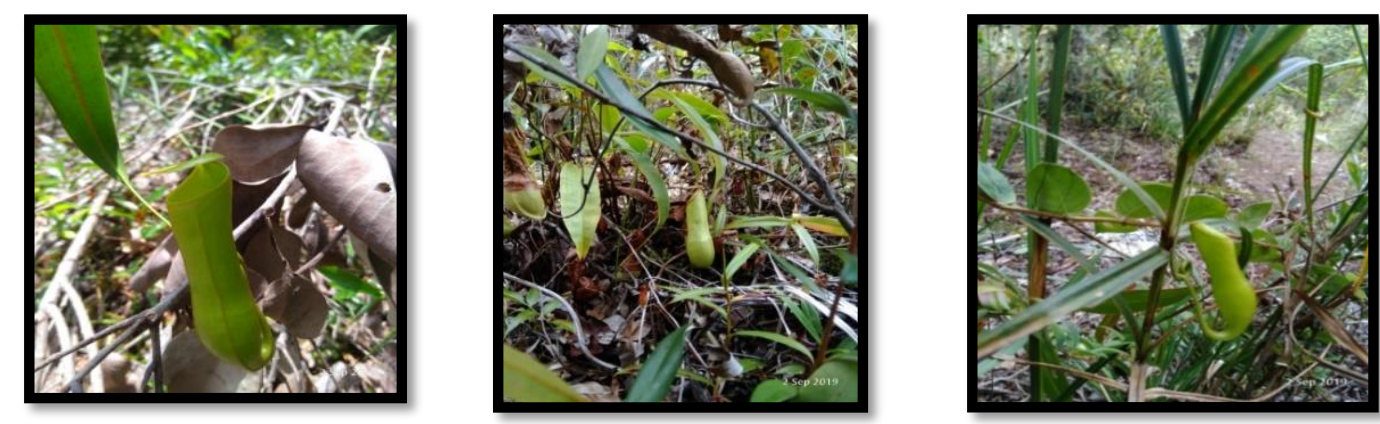

Gambar 7. Nepenthes gracilis warna hijau muda (Nepenthes gracilis light green color (HM)

Nepenthes gracilis hijau muda corak merah (HMM)

Nepenthes gracilis hijau muda corak merah (Gambar 8) ditemukan pada petak ke-1 sebanyak 50 individu di ketinggian 30 mdpl. Petak ke-6 sebanyak 55
36 sebanyak 25 individu pada ketinggian 42 mdpl. Warna daun hijau muda, bentuk daun lanset. Panjang daun 14-18 $\mathrm{cm}$, lebar daun 2-3 cm, panjang sulur 10$15 \mathrm{~cm}$. Panjang batang 30-65 cm, diameter batang 2-3 cm. Bentuk kantong pinggang. Panjang kantong $3-5,5 \mathrm{~cm}$, lebar kantong 2-3,5 cm.Warna kantong hijau muda. 
lanset. Panjang daun 19-25 $\mathrm{cm}$, lebar daun 3-4 cm, panjang sulur $10-15 \mathrm{~cm}$. Panjang batang 20-30 cm, diameter batang 2-3 cm. Bentuk kantong pinggang. Panjang kantong 3-5 cm, lebar kantong 1-3 cm. Warna kantong hijau muda, corak merah.
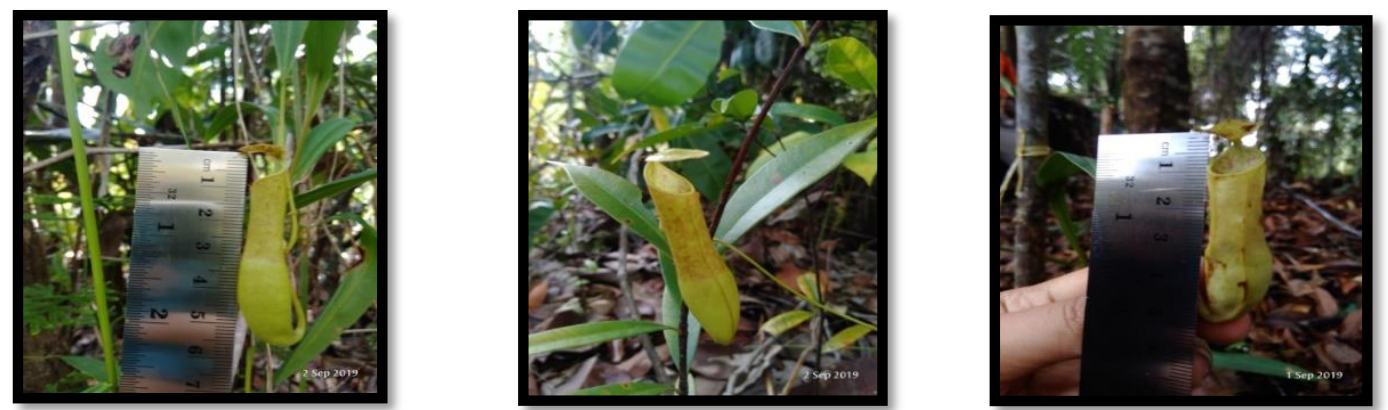

Gambar 8. Nepenthes gracilis warna hijau corak merah (Nepenthes gracilis green color red (HMM)

\section{Nepenthes mirabilis (Lour) Druce}

Nepenthes mirabilis (Gambar 9) ditemukan di petak ke-19 sebanyak 6 individu pada ketinggian $35 \mathrm{mdpl}$. Petak ke-33 sebanyak 38 individu pada ketinggian 40 mdpl dan petak ke-44 sebanyak 45 individu dengan ketinggian
41 mdpl. Panjang daun $25-30 \mathrm{~cm}$, lebar daun $8-10 \mathrm{~cm}$, panjang sulur $10-15 \mathrm{~cm}$. Panjang batang 12-18 cm, diameter batang 2-3 cm. Bentuk kantong pinggang. Panjang kantong 10-18 cm, lebar kantong 3-5 cm. Warna kantong hijau muda kemerahan.
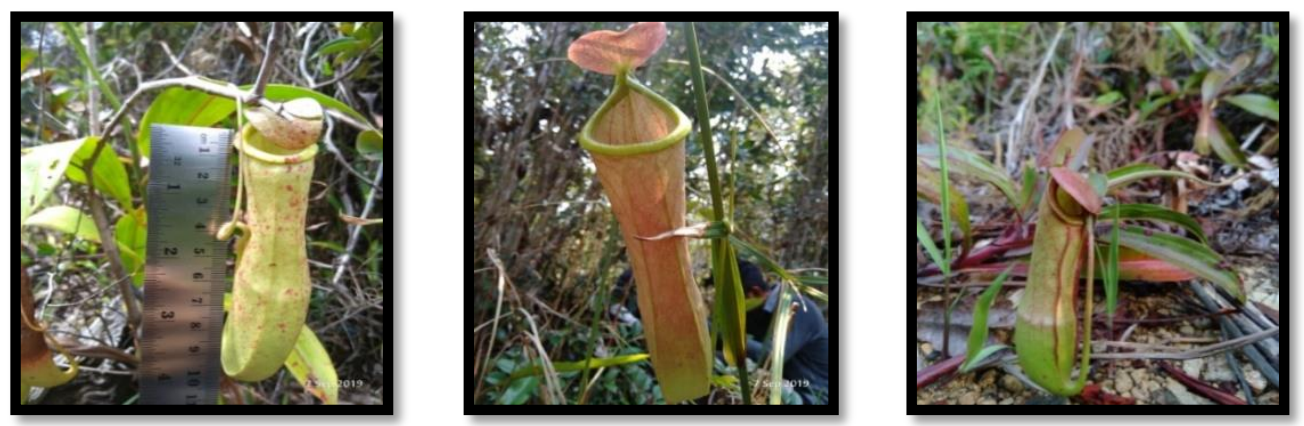

Gambar 9. Nepenthes mirabilis Druce

\section{Nepenthes rafflesiana Jack}

Nepenthes rafflesiana merah tua corak hijau (MTH)

Nepenthes rafflesiana merah tua corak hijau (Gambar 10) ditemukan pada petak ke-8 sebanyak 28 individu pada ketinggian 39 mdpl. Petak ke-9 sebanyak 20 individu pada ketinggian 39 mdpl dan petak ke-13 sebanyak 8 individu pada ketinggian 42 mdpl. Warna daun hijau tua, bentuk daun silinder, panjang daun 10-20 cm, lebar daun 3-5 cm. Panjang sulur $15-25 \mathrm{~cm}$, panjang batang $15-40 \mathrm{~cm}$, diameter batang 2-3 cm. Kantong berbentuk corong (terompet). Panjang kantong 8-20 cm, lebar kantong 3$8 \mathrm{~cm}$. Warna kantong merah tua bercorak hijau.
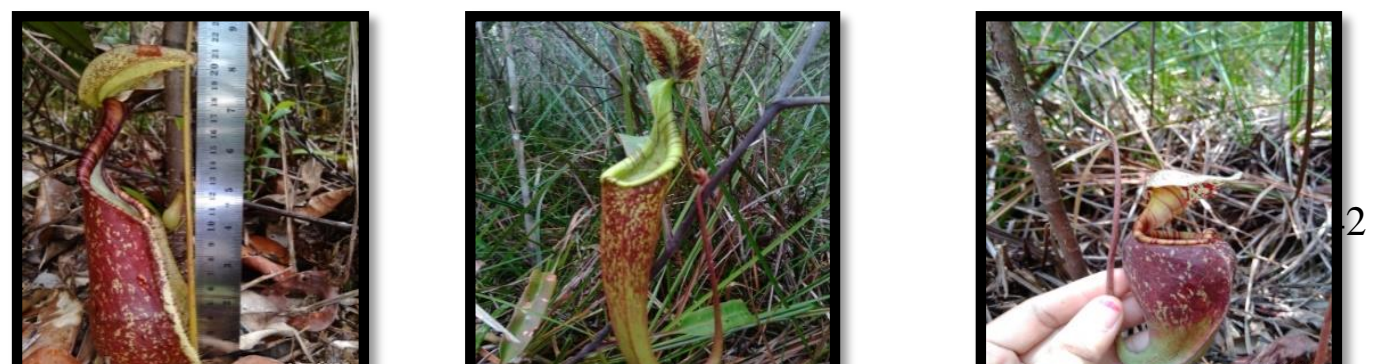


\section{Gambar 10. Nepenthes rafflesiana warna merah tua bercorak hijau (Nepenthes reafflesiana dark red patterned green)}

Nepenthes rafflesiana hijau muda (HM)

Nepenthes rafflesiana hijau muda (Gambar 11) ditemukan pada petak ke20 sebanyak 25 individu pada ketinggian 37 mdpl, dan petak ke-34 sebanyak 5 individu pada ketinggian 40 mdpl. Warna daun hijau tua kemerahan, bentuk daun silinder, panjang daun18-20 cm, lebar daun 3-5 cm, panjang sulur 15-25 $\mathrm{cm}$. Panjang batang $15-35 \mathrm{~cm}$, diameter batang 2,5-3 cm. Kantong berbentuk tempayan. Panjang kantong 10-15 cm, lebar kantong 3-5 cm. Warna kantong hijau muda.
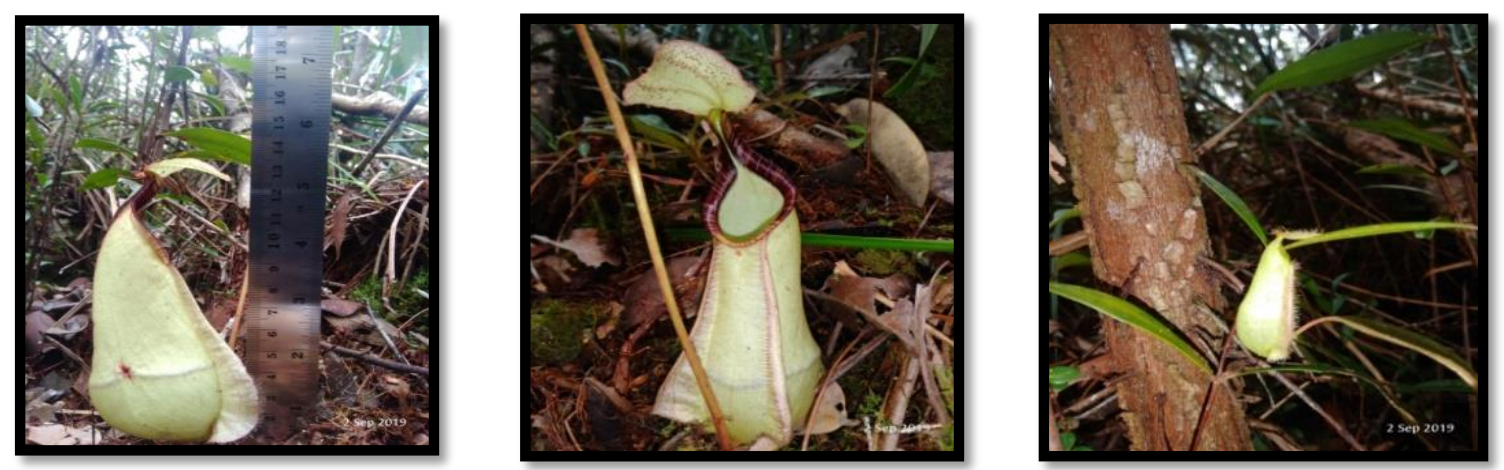

Gambar 11. Nepenthes rafflesiana warna hijau muda (Nepenthes rafflesiana light green (HM)

\section{Nepenthes reinwardtiana Miq}

Nepenthes reinwardtiana (Gambar

12) ini ditemukan pada petak ke-4 sebanyak 10 individu pada ketinggian 40 mdpl. Petak ke-5 sebanyak 25 individu, pada ketinggian 38 mdpl. Petak ke-11 sebanyak 26 individu, pada ketinggian 35 mdpl. Petak ke-12 sebanyak 15 individu, pada ketinggian $37 \mathrm{~m}$ dpl. Petak ke-16 sebanyak 5 individu pada ketinggian 38 mdpl. Petak ke-17 sebanyak 100 individu pada ketinggian
41 m dpl. Petak ke-18 sebanyak 20 individu, pada ketinggian $40 \mathrm{mdpl}$. Petak ke-28 sebanyak 45 individu, pada ketinggian 38 mdpl. Petak ke-29 sebanyak 5 individu dengan ketinggian $41 \mathrm{~m}$ dpl. Petak ke-39 sebanyak 18 individu, pada ketinggian 49 mdpl. Petak ke-40 sebanyak 38 individu pada ketinggian 39 mdpl dan pada petak ke45 sebanyak 15 individu, pada ketinggian 35 mdpl. Warna daun hijau muda, bentuk daun silinder hingga 
corong. Panjang daun 8-15 cm, lebar daun 2-3 cm, panjang sulur $8-15 \mathrm{~cm}$. Panjang batang 30-65 cm, diameter batang 2-3cm. kantong berbentuk pinggang. Panjang kantong 10-12 cm, lebar kantong 2,5-3 cm. Warna yang ditemukan hanya berwarna hijau muda meskipun banyak ditemukan beberapa petak.
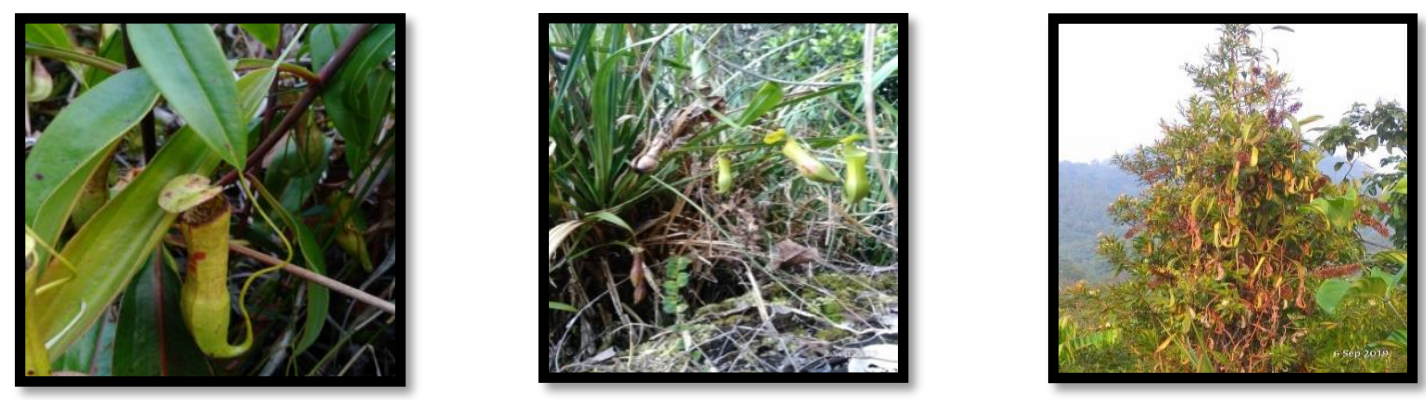

Gambar 12. Nepenthes reinwardtiana Miq

\section{Kesimpulan}

Ditemukan enam jenis (Nepenthes spp) yang terdapat di Hutan Penyangga Dusun Sepan Desa Lanjak Deras Kecamatan Batang Lupar Kabupaten Kapuas Hulu. Jenis tersebut adalah $N$. ampullaria, N. bicalcarata, N. gracilis, $N$. mirabilis, $N$. rafflesiana dan $N$. reinwardtiana.

Jumlah jenis kantong semar terbanyak yang ditemukan di hutan penyangga dusun Sepan adalah jenis $N$. gracilis yaitu sebanyak 829 individu. Sedangkan yang paling sedikit yang ditemukan adalah $N$. bicalcarata yaitu sebanyak 17 individu.

Lima di antara enam jenis Nepenthes spp yang di temukan dilokasi penelitian tergolong kedalam daftar IUCN Red List, ialah $N$. ampullaria, $N$. gracilis, $N$. mirabilis, $N$. rafflesiana dan $N$. reinwardtiana termasuk dalam status konservasi, Least Concern (LC) atau beresiko rendah (IUCN Red List,2016), tidak masuk ke status terancam dan hampir terancam.

\section{Saran}

Kantong semar (Nepenthes spp) merupakan tumbuhan hias yang memiliki nilai konservasi tinggi sehingga perlu diperhatikan dengan pertumbuhannya perlakuan inventarisasi jenis-jenis kantong semar lainnya yang merupakan salah satu tanaman yang dilindungi. Dengan adanya pembinaan pada masing-masing daerah agar setiap jenis kantong semar dapat dilindungi.

\section{DAFTAR PUSTAKA}

Amanda M 2019.

Keanekaragaman jenis kantong semar (Nepenthes spp.) di tutupan lahan semak belukar dan hutan sekunder dusun Gemuruh kecamatan Selakau Timur kabupaten Sambas. Jurnal Hutan Lestari (2) : $844-856$.

Barthlott, W, dan Neinhuis, C. 2007. Purity of the sarced lotus, or scape from contmination in biological surface. Vol. 202: 1-8. https://doi.org/10.1007/s00425005 0096 
Clarke C. 2000. Nepenthes in Sumatera and Penisular Malaysia. Dalam International Carnivourus Plants Society Proceedings: Editor Gray D, Rice BM, Schlauer. International Carnivourus Plants Society Prossiding. San Fransisco. pp 9.

Dariana. 2010. Keanekaragaman Nepenthes dan Pohon Inang di Taman Wisata Alam Sicikeh-cikeh Kabupaten Dairi Sumatera Utara. Medan. [Tesis]. Universitas Sumatera Utara Medan.

IUCN. 2016. Guidelines for application of IUCN Red List Criteria at Regional Land National Levels: Version 4.0. Gland, Switzerland and Cambridge, Uk: IUCN. www.iucnredlist.org (8 Desember 2019)

Khairil, 2015. Studi keanekaragaman jenis kantong semar (Nepenthes spp) di kawasan hutan bukit beluan kecamatan Hulu Gurung. Jurnal Hutan Lestari (2) : $259-264$.
Kristianus, Dwi A, Ratna H. 2018. Keanekaragaman jenis kantong semar (Nepenthes spp) di berbagai kondisi tutupan hutan sekunder desa Bukit Batu kecamatan Sungai Kunyit kabupaten Mempawah. Jurnal Hutan Lestari (2) : 318 328.

Kusmana, C. 1997. Ekologi dan Sumberdaya Ekosistem Mangrove. Bogor: Jurusan Manajemen Hutan Fakultas Kehutanan IPB.

Mansur M, 2006. Nepenthes: Kantong Semar yang Unik. Jakarta: Penebar Swadaya.

Mansur M, 2008. Laju penyerapan $\mathrm{CO}_{2}$ pada kantong semar (Nepenthes gymnamphora Nees) di Taman Nasional Gunung Halimun-Salak, Jawa Barat. Jurnal Teknologi Lingkungan. 1: 59-65.

$\begin{array}{rr}\begin{array}{c}\text { Mansur Minjauan } \\ \text { tentang } \\ \text { (Nepenthaceae) di }\end{array} & \begin{array}{r}\text { Nepenthes } \\ \text { Indonesia. }\end{array} \\ \text { Jurnal Ilmu-ilmu Hayati. 12: 1-8. }\end{array}$

